Artículo de investigación

\title{
Evaluation of physicochemical characteristics of four brands of ultrapasteurized milk in the Cundiboyacense region- Colombia
}

Evaluación de características fisicoquímicas de cuatro marcas de leche ultrapasteurizada en la región Cundiboyacense -Colombia

\section{Avaliação das características físico-químicas de quatro marcas de leite ultrapasteurizado em região Cundiboyacense-Colômbia}

Luis Edgar Tarazona Manrique 1, emvz, cvlac; Julián Ricardo Villate Hernández 1, emvz, cvLAC; Elkin Josué

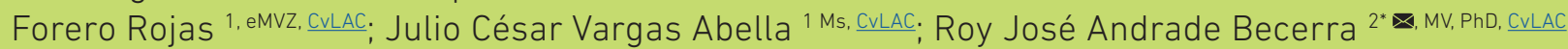

Fecha correspondencia:

Recibido: 27 de Julio de 2019.

Aceptado: 25 de noviembre de 2019.

Forma de citar:

Tarazona Manrique LE, Villate

Hernández JR, Forero Rojas EJ,

Vargas Abella JC, Andrade Becerra

RJ. Evaluación de características

fisicoquímicas de cuatro marcas

de leche ultrapasteurizada en la

región Cundiboyacense -Colombia.

Rev. CES Med. Zootec. 2019; Vol

14(3): 8-15.

Open access

(c) Copyright

Creative commons

Éthics of publications

Peer review

Open Journal System

DOl: http://dx.doi.org/10.21615/

cesmvz.14.3.1

ISSN 1900-9607

Comparte

\section{Abstract}

Decree 616 of 2006 determines what should be the physicochemical characteristics that dairy products must contain in Colombia, however, not all times these parameters are followed to the letter, thus affecting the final quality of the product received by the consumer. The objective of this work was to determine the physicochemical characteristics of four brands of UHT milk produced in Boyacá and compare them with national regulations. The physicochemical characteristics of four trademarks of ultrapasteurized milk, produced and consumed in the Cundiboyacense region, Colombia, were evaluated through the MilkoScanTM MARS technique, determining the percentages of protein, fat, lactose, total solids and non-fatty solids, in addition to the point of freezing and comparing it with the current national regulations. An ANOVA was performed between each trademark evaluated and significant differences were found for one of these trademark in comparison with the other three in the variables under study $(p<0.05)$. It was found that none of the trademark complies with the minimum parameters stipulated in the Colombian regulations.

Keywords: milk, ultrapasteurized, normativity, physicochemical characteristics, MilkoScan.

\section{Resumen}

El decreto 616 de 2006 determina cuales deben ser las características fisicoquímicas que deben contener los productos lácteos en Colombia, sin embargo, no en todas las ocasiones estos parámetros son seguidos al pie de la letra, afectando así la calidad final del producto que recibe el consumidor. El objetivo del presente trabajo fue determinar las características fisicoquímicas de cuatro marcas de leche UHT producidas en Boyacá y compararlas con la normatividad nacional. Se evaluaron las características fisicoquímicas de cuatro marcas de leche ultrapasteurizada, producidas y consumidas en la región 


\section{Filiación:}

"Autor para

correspondencia: Roy José

Andrade Becerra. Correo de

correspondencia:

roy.andrade@uptc.edu.co

${ }^{1}$ Investigadores

pertenecientes al Grupo de

Investigación en Producción

Animal del Trópico Alto

Colombiano- GIPATRACOL.

Línea de investigación en

calidad de leche. Escuela

de Medicina veterinaria

y zootecnia, UPTC. Tunja-

Colombia.

$2^{2 *}$ Grupo GIPATRACOL. Línea de investigación en calidad de leche. UPTC. Avenida Central del Norte 39-115. Edificio nuevo de Laboratorios, LN403. cundiboyacense, Colombia, a través de la técnica MilkoScan ${ }^{\mathrm{TM}}$ MARS, determinando los porcentajes de proteína, grasa, lactosa, solidos totales y solidos no grasos, además del punto de congelación y comparándola con la normatividad nacional vigente. Se realizó un ANDEVA entre cada una de las marcas evaluadas y se encontraron diferencias significativas para una de estas marcas en comparación con las otras tres en las variables en estudio $(p<0,05)$. Se encontró que ninguna de las marcas cumple con los parámetros mínimos estipulados en la normatividad colombiana.

Palabras clave: leche, ultrapasteurización, normatividad, características fisicoquímicas, MilkoScan.

\section{Resumo}

Decreto 616 de 2006 determina o que as características físico-químicas que os produtos lácteos devem conter na Colômbia deve ser, no entanto, não em todas as ocasiões estes parâmetros são seguidos para a carta, afetando assim a qualidade final do produto que o consumidor recebe. 0 objetivo deste trabalho foi determinar as características físico-químicas de quatro marcas de leite UHT produzidas em Boyacá e compará-las com as regulamentações nacionais. As características físico-químicas de quatro marcas de leite ultrapasteurizado, produzidas e consumidas na região de Cundiboyacense, Colômbia, foram avaliadas por meio da técnica MilkoScanTM MARS, determinando as porcentagens de proteínas, gorduras, lactose, sólidos totais, sólidos não gordurosos, e ponto de congelamento e comparando-o com as regulamentações nacionais vigentes. Foi realizada uma ANOVA entre cada marca avaliada e foram encontradas diferenças significativas para uma dessas marcas em relação às outras três nas variáveis estudadas $(p<0,05)$. Nenhuma das marcas foi encontrada para atender aos parâmetros mínimos estipulados nos regulamentos colombianos.

Palavras chave: leite, ultrapasteurizado, normatividade, características físico-químicas, MilkoScan.

\section{Introduction}

According to ${ }^{10}$ Federación Panamericana de Leche (FEPALE, 2014), milk is the most complete and irreplaceable meal for humans due to its organoleptic and nutritional characteristics. It contains elements that mammals need for construction and maintenance of its body, like fat, protein, and carbohydrates ${ }^{7,12,21}$. Nevertheless, these conditions also allowance microorganisms growth and this decreases its useful life and can affect health public due to microorganisms or toxin's consumption. Therefore it is necessary the addition of industrial processes that enable its conservation (eliminating and preventing microorganism's growth), facilitating its consumption and commercialization ${ }^{23}$.

Principally to ensure its quality, milk is undergoing to heat process like ultra-pasteurization, which that is defined like heating of milk to a temperature that is between 135 and $145^{\circ} \mathrm{C}$ for two and four seconds, with a subsequent packing and the objective is the destruction of potentially pathogens microorganisms of this product ${ }^{16}$. UPM's quality depends first: of the physicochemical quality of raw milk, and second that the thermic process it would have been entirely adequate ${ }^{13,5,25}$. Also, this is the most common form of milk commercialization in the country ${ }^{14}$.

In Colombia, for finals of 2018, monthly milk production was 3'414.000.000 liters, and an average of UPM production of $27^{\prime} 000.000$, mostly in Cundinamarca department ${ }^{17}$. Due 
to ultra-pasteurization is the most common process used in Colombia, and is the most common form of consume, is necessary to evaluate physicochemical parameters of regional trademark of this type of milk to determine its quality and demonstrate if it satisfies the national normativity, as Briñez et al., 2002 in Venezuela and Juárez et al., 2015 in Mexico.

These analyses are performed generally following the instructions of the Official Methods of Analysis (AOAC) or national's institutions that stipulate manual processes like Gerber, Kjendal, or evaporation in the stove ${ }^{7,3,19}$. Nevertheless, the Fourier-transform infrared spectroscopy (FT-IR) is more relevant daily due to the necessity to obtain quick and confirmability results $5,6,9,12,15,22,24$.

Therefore, the objective of this study was to determine the physicochemical characteristics of four trademarks of ultra-pasteurized milk for human consumption in the Cundiboyacense region and compare the results with the national normativity.

\section{Materials and methods}

\section{Type of study}

A non-probalistic convenience sampling was performed. The number of samples was selected based in previous studies performed by Juárez et al., 2015. Sampling and processing of the samples were developed between July of 2018 and April of 2019.

\section{Parameters for selection}

The parameters determined for selection of the samples were: 1-liter packaging, without fat or lactose extraction, without flavors addition, and the expiration dates for each sample had to be more than six months, taking a count day of sampling. Trademarks were identified like 1, 2, 3 and 4, and all of them were replicated 20 times, which means 20 samples for each trademark. The companies included are independents between them.

\section{Sampling}

Eighty samples of four trademarks of UPM produced in the Cundiboyacense region, Colombia, were sampled every 15 days directly from supermarkets in Tunja-Colombia. It was verified that all products it was refrigerated in a temperature of $4{ }^{\circ} \mathrm{C}$ (value determined through thermometers in each refrigerator) and that lot fabrication it was different.

\section{Study variables and processing}

Were determined the percentage (\%) of protein, fat, total solids, not fatty solids and lactose, as well freezing point $\left({ }^{\circ} \mathrm{C}\right)$ through an equipment MilkoScan ${ }^{\mathrm{TM}}$ Mars of FOSS company which use FT-IR for analyses of samples. For this, $10 \mathrm{~mL}$ of each sample was taken and packaged in an aseptic plastic container to introduce in the equipment. The machine is located at the laboratory of milk quality and mastitis control, of the veterinary medicine and zootechny school of the Universidad Pedagógica y Tecnológica de Colombia, in Tunja-Boyacá.

\section{Parameters of national normativity}

The analysis of the mostly ranks determined here was made with the values stipulated through the ${ }^{18}$ decree number 616 of the Ministerio de la Protección Social and the technic paper for aliments of Instituto Colombiano de Bienestar Familiar ${ }^{14}$. These documents are part of the current national regulations. For the case of the 
protein the comparison was made following the modified classification effectuated by ${ }^{8}$ Calderón et al., 2006, thereby: Excellent (>3.2\%), Good (2.8\%-3.19\%), Moderate $(2.6 \%-2.79 \%)$ and Poor $(<2.6 \%)$.

\section{Data analysis}

An analysis of variance (ANOVA) was performed between trademark using comparations of the average of the low significative differences of Fisher's procedure with a confidence level of $95 \%{ }^{15}$.

\section{Results}

Averages values found for each physicochemical parameter of the trademarks evaluated and the values stipulated in the decree number 616 of 2006 are shown in Table 1. The trademark four has not statistical difference compared with the trademarks two and three; the trademark one is statistically different from the other three trademarks (Table 1).

For protein percentage, trademark four is classified in the poor rank $(<2.6 \%)$ and was statistically different compared with trademarks two and three; on the other hand, trademark one is classified in the moderate rank, and was similar to the trademarks four and three; meanwhile trademarks two and three were classified in the rank good, and are statistically similar, and only trademark one is totally different statistically with the trademarks four and one (Table 1)

For the lactose percentage, only the trademark one was statistically different compared with other trademarks. No one trademark meet national standards related with not fatty solids and total solids percentage. Statistically, trademarks one and two were similarly, compared with trademark four and one, the trademark four was also statistically different from the trademark one. Something similar happened with total solids percentage, however, here only trademark one was statistically different from the other three trademarks. The freezing point neither was satisfied for no one trademark, the trademark one was statistically different from the other three trademarks (Table 1)

Table 1. Mean values of the physicochemical composition of four trademarks of UPM and ranks specified by the national normativity and other references

\begin{tabular}{|c|c|c|c|c|c|}
\hline \multirow{2}{*}{ Parameters } & \multicolumn{4}{|c|}{ Trademarks } & \multirow{2}{*}{ National regulations } \\
\hline & 1 & 2 & 3 & 4 & \\
\hline$\%$ Fat & 1.16 & 2.91 & 2.94 & 3.01 & $3 \%$ minimum \\
\hline$\%$ Protein & 2.73 & 2.96 & 2.86 & 2.59 & $* *$ \\
\hline$\%$ Lactose & 4.0 & 4.38 & 4.33 & 4.46 & $*$ \\
\hline$\%$ Not Fatty Solids & 7.48 & 8.06 & 7.92 & 7.77 & $8.20 \% \min$ \\
\hline$\%$ Total Solids & $8.64+-0.56$ & 10.9 & 10.8 & 10.73 & $11.20 \% \mathrm{~min}$ \\
\hline Freezing Point ${ }^{\circ} \mathrm{C}$ & -0.436 & -0.493 & -0.475 & -0.492 & $-0.540 \mathrm{max} /-0.510 \mathrm{~min}$ \\
\hline
\end{tabular}

* National normativity does not have ranks for lactose percentage

${ }^{* *}$ Comparison made with parameters of ${ }^{8}$ 
Septiembre - diciembre 2019 - Página 12

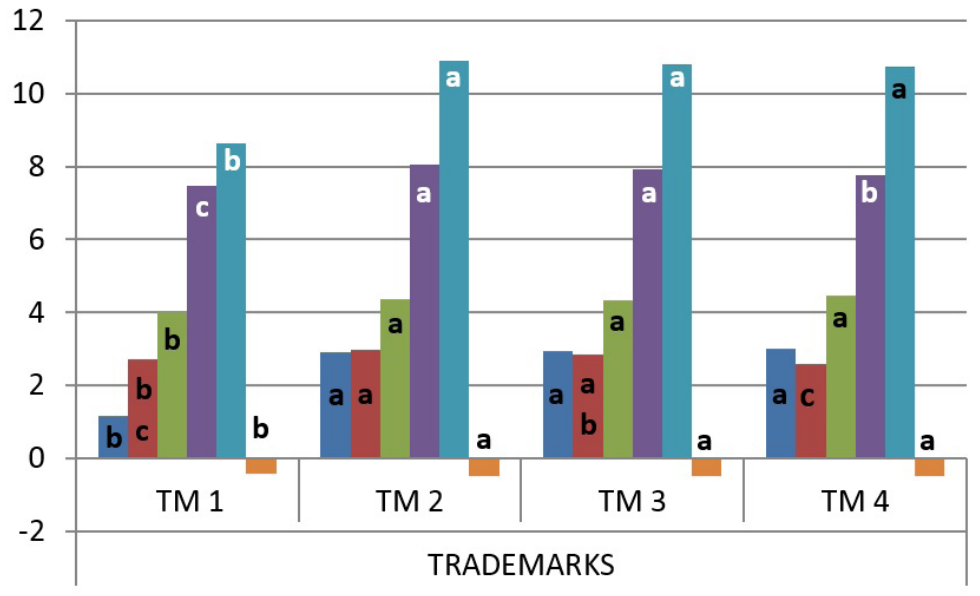

\% FAT

\% PROTEIN

\% LACTOSE

\% NOT FATTY SOLIDS

\% TOTAL SOLIDS

FREEZING POINT 으

Figure 1. Statistical differences between each trademark for each parameter evaluated.

\section{Discussion}

Only are a few studies, around the world, related to the evaluation of the physicochemical characteristic of milk pasteurized or ultra-pasteurized, and its comparison with the national normativity. For example, in Mexico, ${ }^{15}$ Juárez et al. 2015 performed a similar study with UPM, but in Venezuela ${ }^{7}$ Briñez et al. 2002 performed it study in pasteurized milk, while authors like ${ }^{6}$ Bernal et al. 2007 performed studies in raw milk.

The decree 616 of $2006{ }^{18}$ stipules $3 \%$ as the minimum value for the fat percentage for the UPM, only the trademark four satisfies this value; no one other trademark meets this parameter. ${ }^{15}$ Juárez et al., 2015 in Mexico show that all trademarks of UPM evaluated, meet the national normativity in this country contrary to find in this study, on the other hand, ${ }^{7}$ Briñez et al. 2002 for pasteurized milk also find that all trademarks satisfy the Venezuelan normativity related with the fat percentage. This lower fat percentage content can be due primarily to low fat content in raw milk affected by nutrition of animals, or by water addition in any process since storage in farms, transport and UHT process, especially in trademark 1 which present the smaller values for all parameters (Figure 1)

No one trademark is in the classification of excellent for protein percentage, following the ranks of ${ }^{8}$, and also are smaller compared with national average stipulated by government (3,66\%) ${ }^{17}$. In Mexico ${ }^{15}$ Juárez et al., 2015 also shows that protein percentage of UPM does not satisfy national normativity, but ${ }^{7}$ Briñez et al., 2002 reported that pasteurized milk satisfy the normativity. This nutritional deficiency can be related first with the quality of raw milk (due to season, or mammary glands disease) ${ }^{2}$, or the covalent association between serum proteins and proteins of fat globules due to the thermic process ${ }^{26}$, process known like maillard reaction.

Colombian normativity does not stipule ranks for lactose content, even when this carbohydrate is part of the not fatty solids and fatty solids of milk, and is highly related with freezing point according to report by ${ }^{5,27,15}$. This parameter can be associated also with water addition due dilution factor, this is correlated principally whit trademark 1 which have the lower content of lactose percentage?. 
For the not fatty solids, Colombian normativity stipule $8,20 \%$ like reference value, however, no one trademark meets this, these results are similar to reported by ${ }^{15}$, in which no one trademarks evaluated accomplish Mexican normativity. For total solids, no one trademarks also meet national normativity. Both values can be affected by water addition in any part of the fabrication process, and therefore affect too freezing point, the results of Table 1 shows that no one trademark satisfy national normativity, and added to values found for not fatty solids therefore, it is highly probable that there was addition of water $4,8,11,20,27$.

Figure 1 shows the statistical differences between each parameter of each trademark of UPM, trademark 1 have the smaller value for each parameter and was different compared with others trademarks. These shows two situations, first, even each trademark is elaborated in different parts of the cundiboyacense region, the results for physicochemical characteristics is similar between its, so, the smaller values found for trademark 1 can be due to poor productive practices in some part(s) of the productive process, which shows the importance of raw milk quality and a good transformation process to guarantee the nutritional quality of the product

\section{Conclusions}

The results of physicochemical analyses performed to four trademarks of UPM produced and marketed in the Cundiboyacense region, shows that the no one of them doesn't accomplish completely national normativity to be sold to the final consumer.

\section{References}

1. Andrade RJ, Pulido MO, Rodrígez CE. Sanidad de ubre, calidad de leche. 1ra ed. Colombia. Universidad Pedagógica y Tecnológica de Colombia; 2012.

2. Andrade RJ, Vargas JC, Caro ZE. Importancia del conteo de células somáticas en la calidad de la leche de vaca. 1 ra ed. Colombia. Universidad Pedagógica y Tecnológica de Colombia; 2018.

3. Artica L. Métodos para el análisis fisicoquímico de la leche y sus derivados. 2 da ed. Perú: Libros y Editoriales TEIA. 2014.

4. Badui DS. Química de los alimentos. 5da ed. México: Ed Pearson. 2013.

5. Bermúdez D, Mawson R, Versteeg K, Basbosa G.. Composition properties, physicochemical characteristics and shelf life of whole milk after thermal and thermo-sonication treatments. J Food Quality 2009. 32: 283-302.

6. Bernal LR, Rojas MA, Vázquez C, Espinoza A, Estrada J, Castelán, OA. Determinación de la calidad fisicoquímica de la leche cruda producida en sistemas campesinos en dos regiones del Estado de México. Vet México 2007. 8: 395-407.

7. Briñez WJ, Valbuena E, Castro G, Fuentes F, González D, Tovar A. Calidad fisicoquímica de las principales marcas de leche pasteurizada consumidas en la ciudad de Maracaibo. Rev Cient. Fac. Cien. Vet. 2002. 7: 221-230.

8. Calderón A, García F, Martínez G. Indicadores de calidad de leches crudas en diferentes regiones de Colombia. Rev MVZ Cordoba 2006. 11: 725-737. 
9. Chugh A, Khanal D, Wlakling M, Correding M, Duizer L, Griffiths M. Change in color and volatile composition of skim milk processed with pulsed electric field and microfiltration treatments or heat pasteurization. Foods 2014. 3: 250-268.

10. Federación Panamericana De Leche-FEPALE. Lácteos: alimentos esenciales para el ser humano (¡Sí a la leche!). 1ra ed. Uruguay. FEPALE. 2014.

11. García E, Fernández I, Fuentes A. Determinación de la grasa por el metodo Gerber. 2013. [acceso el 17 abril de 2019] URL: http://hdl.handle.net/10251/30627

12. Gathercole J, Reis MG, Agnew M, Reis MM, Humphrey R, Harris P, Clerens S, Haigh B, Dyer J. Molecular modification associated with the heat treatment of bovine milk. Int. Dairy J. 2017. 73: 74-83.

13. Hinrichs J. UHT processed milk concentrates. Le Lait 2000. 80: 5-23.

14. Instituto Colombiano De Bienestar Familiar-ICBF. 2016. Fichas técnicas alimentos. Grupo leche y productos lácteos. [acceso el 15 de abril de 2019] URL: https:// www.icbf.gov.co/sites/default/files/procesos/a27.g6.pp_fichas tecnicas grupo leche y productos lacteos v1.pdf

15. JuáreZ J, Rodríguez J, Martínez CE, Hernández B, Paz E, Gómez C, Díaz P, Herman L. Evaluación y clasificación de calidad de leches comerciales consumidas en Tuxtepec, Oaxaca, México. Ecos Rec Pec 2015. 2: 327-337

16. Lucey J. Raw milk consumption: risk and benefits. Nutr Today 2015. 50: 189-193.

17. MINISTERIO DE AGRICULTURA Y DESARROLLO RURAL-MADR. S.f. Unidad de Seguimiento de Precios de Leche. [acceso el 15 de julio de 2019] URL: http://ftpleche.minagricultura.gov.co/

18. Ministerio de la protección social-MPS. DECRETO 616 DE 2006 por medio del cual se expide el reglamento técnico sobre los requisitos que debe cumplir la leche para el consumo humano que se obtenga, procese, envase, transporte, comercializa, expenda, importe o exporte del país. [acceso el 10 de enero de 2019] URL: https://www.ica.gov.co/getattachment/15425e0f-81fb-4111-b215-63e61e 9e9130/2006D616.aspx

19. Molero M, Castro G, Briñez W. Evaluación fisicoquímica del lactosuero obtenido de la producción de queso blanco aplicando un método artesanal. Rev Cient Fac Cien Vet. 2017. 27: 149-153.

20. Navrátilová P, Janštová B, Glossová P, Vorlová L. Freezing point of heat-treated drinking milk in the Czech Republic. Czech J Food Sci 2006. 24: 156-163.

21. Park YW, Haenlein GF, Ag D. Milk and dairy products in human nutrition. 1ra ed. USA. Wiley-Blackwell. 2013.

22. Pereda J, Jaramillo DP, Quevedo JM, Ferragut V, Guamis B, Trujillo AJ. Characterization of volatile compounds in ultra-high-pressure homogenized milk. Int. Dairy J. 2008. 18: 826-834. 
23. Programa De Las Naciones Unidas Para El Desarrollo-PNUD; Departamento Para La Prosperidad Nacional-DPS. Estudio del perfil ocupacional en la cadena agroindustrial de lácteos. Perspectivas e identificación de oportunidades de inclusión socioeconómica en Boyacá. 1 ra ed. Colombia. PNUD. 2015.

24. Rodríguez C, Gómez D, Moyano M. Efecto de la suplementación con alimentos ricos en ácidos grasos sobre parámetros productivos y composicionales de la leche bovina. Ciencia y Agricultura 2014. 11: 77-82.

25. Superintendencia De Industria Y Comercio-SIC. Análisis del mercado de la leche y derivados lácteos 2008-2012. 1 ra ed. Colombia: SIIC. 2012

26. Walstra P, Walstra P, Wouters JT, Geurts TJ. Dairy science and technology. 1ra ed.USA. Taylor \& Francis Group. 2006.

27. Zagorska J, Ciprovica I. Evaluation of factors affecting freezing point of milk. Int J Nutr Food Engineering 2013. 7: 106-111. 